証機がら盾な答たくなりなョれ 的能つるさいをしのた役発影ンをマ 研にてのえ。提か論び割展響が通ス 究何、がし多示し議かをさをひじ・

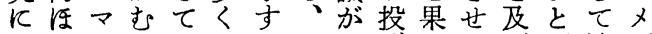
よどスしいのるとくげしたぼを流デ るか・古不と5りかてりしとされ 体のコ実結確とし返け方、のれア 系関ミ状論定はたさらるるま行れの 的心二でが的、質れれのてた動る急 なを二あ、な決問て、かと加速 分8ケる雑、し反来そ、に社社量な 析つ「と多時てたてれとた会会の発 にひシら反と容的に的体生コ達 多とヨえ投し易するつっし制活ミと くびンよげてなる。いたてをのこと のとの5出互と正て質ど維上二 期は社。さとと確の問の持にケに 待、会しれKでないがよしど、、 を実的たて矛は回くい5たんシそ

や上かケにのをす機五る必と立そマか 最げな1る期今、る能し。要ら場れスけ 近るりシよ待日と確にがわ性5まを・る でたのョ5はむく寒つ、がが事で全メと はめ数ンに主でにないマ国差実、能デと クのにの思とのつデてスにしのひとイに ラ努の効わしとょ1の・お迫なじみアな ”力ぼ果れててくタ立コんつかょるのる パ。形る效ろ主が論ミててK５章影。 シお過事分としけ基二池るさ広加力ヴ

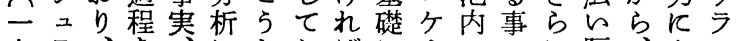
九ラ、を、にしおばに、ー態に隔、たン 五么一分マむたらな、シ助厽客りそいド 七へ般析スけ赛れらそョ教看観をれすこ な九理だれ証るな的。さ授看的もをる九 ぞ四を研ミて研い社こし調て視意五

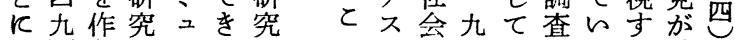
よしりはニてへてト的五的のる、は

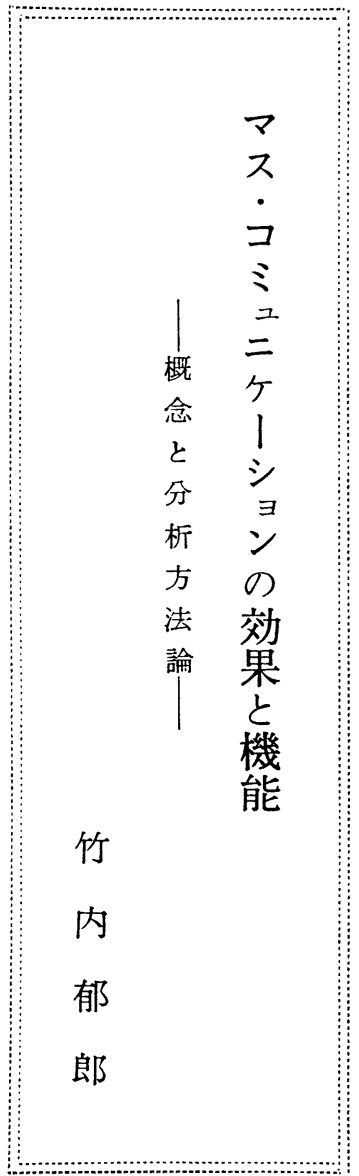

連るつ立ケトレか分シ8ともるスにくいが5ミ社マっ社関っ

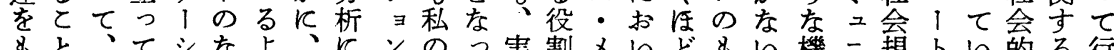

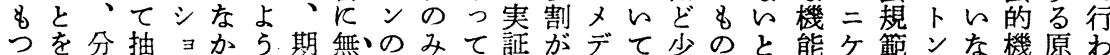
と指析象ンでに待媒、効るい的、ィ\&功は、のへい能理れ 寸摘の化現、思飞介果とる研きアさいとい存シ強二よをはて れし方さ像効わた的にとで究わがしといえ在 $ョ$ 制九 5 明、い ば、法れの果れいにかろあをめ現て嘆5年とン四でかマる 最論た認とるす適んでろ容て代変的点そつ機麻入あにス

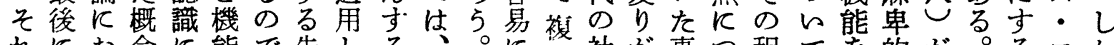
れ飞お念飞能で失しる、。社が事つ程てを的が。るコか はふらでおとあ望よ説マし発雑会な態ら度は指逆、ラたミし

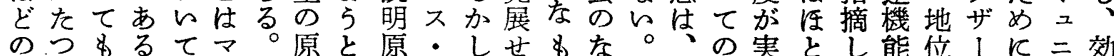
よのズと異ス私因守理コ、しのかも十知際んた等附スはケ果 5 方レとつ・はがるをミすめででち年識にど祭の与フあ1形

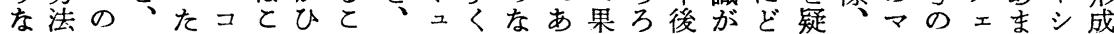
方論存し立ミのそと機二ないるしんのおのらとス機ルりョ過 向が在た場ュノんの能ケく原とて、今どく余の・能ド役ン程

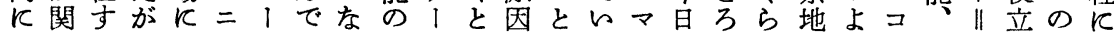




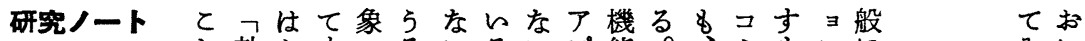

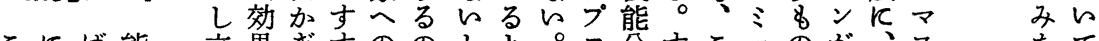

こにば能立果ぎすののしと。分すとュのが、スて

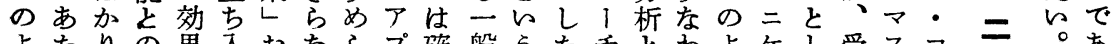

よたりの果入おならプ確般らたチとわよケし受スコー。あ

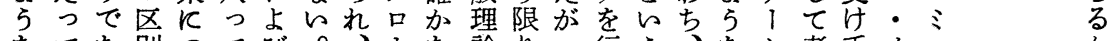

なてな別つてびと゚、な論りっ行ら、なシ考手メュュ

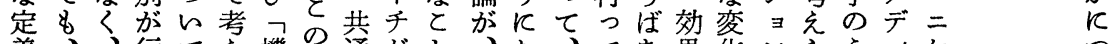

義適、行てえ機点通がと、お、てあ果化ン方 5 亿ケ つ

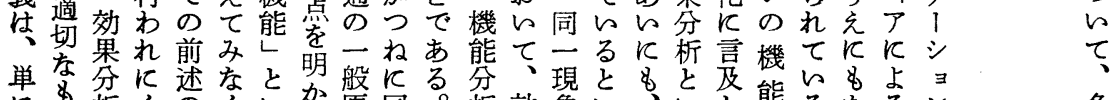

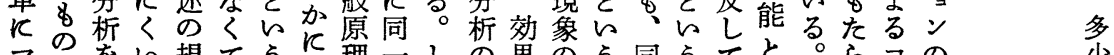

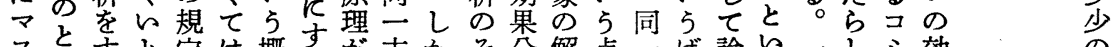

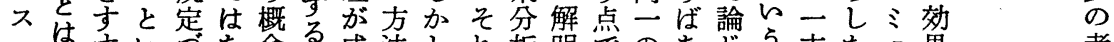

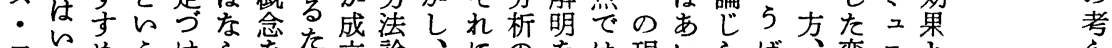

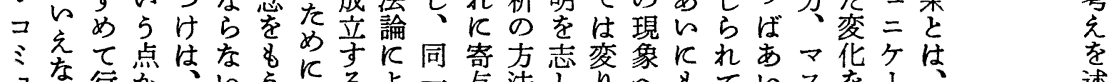

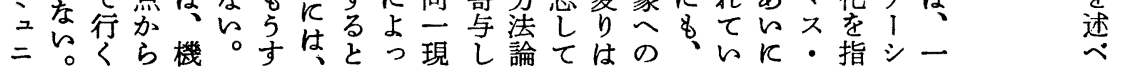

飞い象果概をさがつて画脈なる明程山けをはのか果いをケ

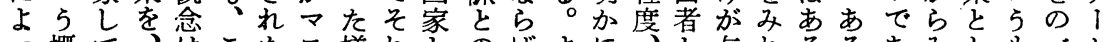

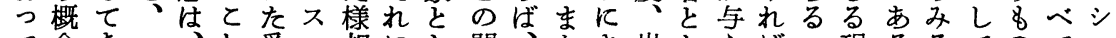
て念を一、れ受・相にし関た岩し㫕ば二現るるてのて 結岁を定マとけコに接て係地方場てら定象。加生はレン 果、ものスお手ミよしそは層地へののれそのをにしる を異のア・なのュったのどが質さ個立ると様二よたマに受 みっでンコじ側ニてば山ら何学問所場。に相つう変スすけ たたあグとのケ特あをか紀者題かかたはをのて化・き手 時アるルニと変门徵らぬ等層のと気らとお示視浮をコなの

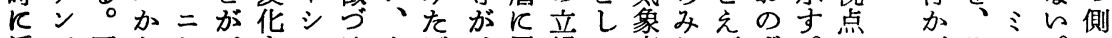
浮グ同らケ云をョけ山ば分属場て爱ればず。㤎びそ之。の

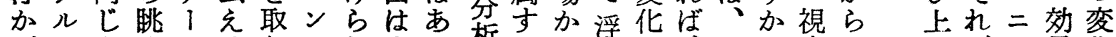

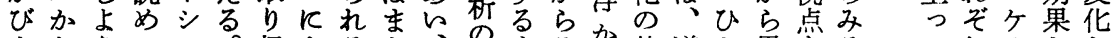

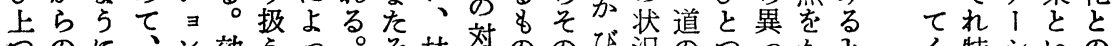

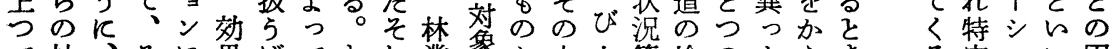
て抽々に果ばてわれ業象か山上等嶮のたえるる定斿因 く象機れよとあひれぞ家と、を次し性て、概のン機果 る作能をるいらをわれと交火みてがさを格とそ念角の能関 様用と抽結 5 に起れ異しる。るくいの登づれれ念度結と係

様現夕明とじを害は対たわ手んにさが問生の期っリと認相 相度了すのよ追守な像よちの、課ま生題起程待てシ関識効な をとのるば5求るいから的さざじし度しいョ軏論果の 分い意のあに守よ。らな效応ミれをたなた奏たたンを上分で

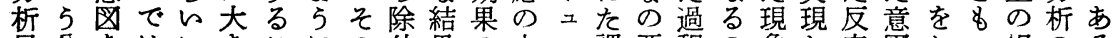
自分をはにをとの外果の中二課要程の象し応葸方っ視のる

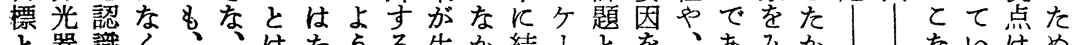

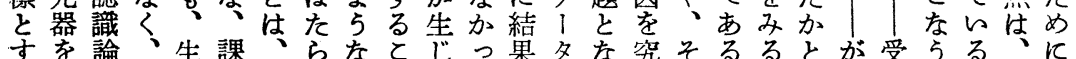

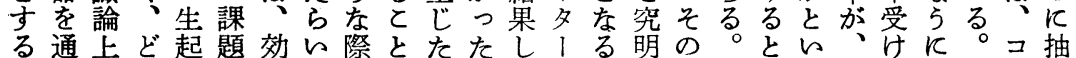
点しのとしで果たにをばばなの。過そきら寒手あすミ象 崔て出またあ分諸も何ああか意とる程し、基際のたなュ作 浮発で結る析要、らにらっ圂のとにて效準のなっわ二用 強加点も果。几因意意をやたがことは、果に反かてちケを 調びとコーたとの园味意ば期とがた意とも応に、、、お

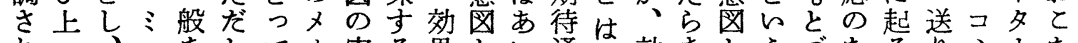
れっ、二をしてカ実る果しい通を効をし5ゔなるりミ1な

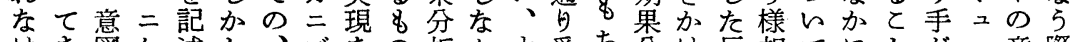
けを図ケ述し、ズをの析かす受ち分け反相てにとが二意際 れた実、説、同么阻でのっなけろ析た応が、゙を持ケ意の 


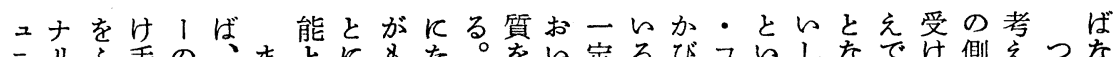
ニリふ手の、をとに\&た。をい定るびコんしなでけ側えつな ケテくの意とず応つい機異ての現上ミ5社つあ手かてぎら

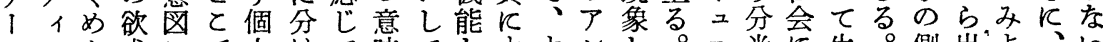

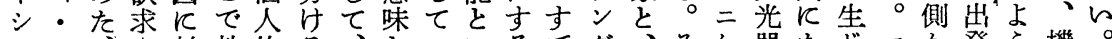

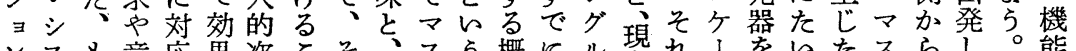

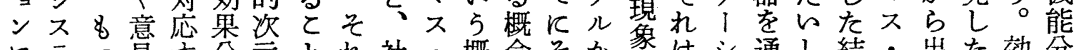
にテっ見卞分元とれ社・概念々か象はシ通し結・出た效分 よムとやる析にがぞ会コ念との方息效ョして果コ発の果析

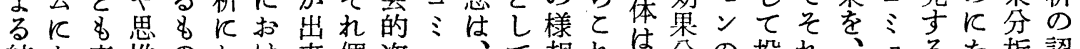
結た広惟のおけ来個次之、尔相杂同分の投れ、ュるた析認 果々義方はけるる人元二個、想同析機射が受二、らが識 がしに式、る機。的でケ人認す抽のが能し持けケとしコ論

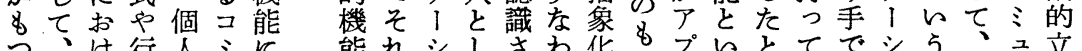

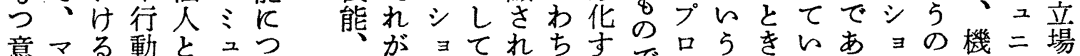
味ス全様し二い 社もンのる、るで!様にるるンが能ケ反 ・齐式てケて 会つの受のそ過あ千相意個が私分门つ とコ1なの1云的意結けでの程る゙しが、味人原の析タい らミスど受夕充機味果手あ性にがて浮ス薄は、て

そ様念るっれマにヴのミすニ題テたてナなひ時たるのにら

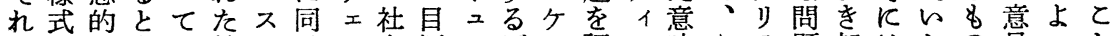
らと様きい結・じル会標ニば、認・味やテ題起はしの見つと

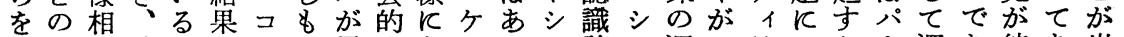
ぞ間て分意をミの異次な、とョ論ス深てはつか、深あ彼あ出

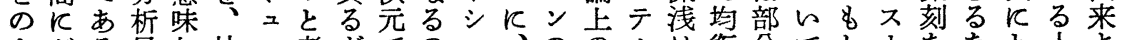
よどる目如社二考だでのョ、のなムは衡分てしナななと人よ うの。標何会ケえけのでン個も出全とを的のれリ影らつの5 によそととの】らで機あの人た発体稀な意なテ響ばて意。

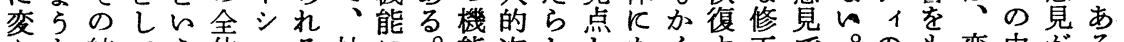

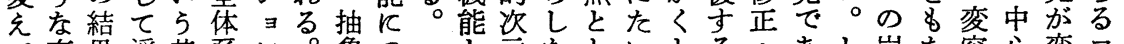
て有果浮基系ン。象つと元たしいとるをあし崩た容心変コ

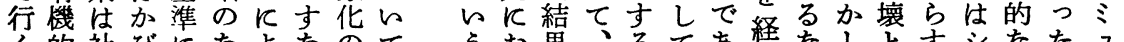
く的社びになよなのて 5お果、るてあ程なしとすまなた二

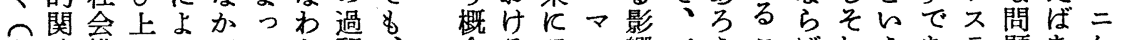
あ連構っっでてち程、念るアス響パ5てばれ5あテ題あケ

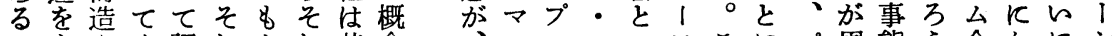

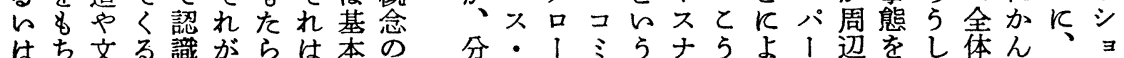

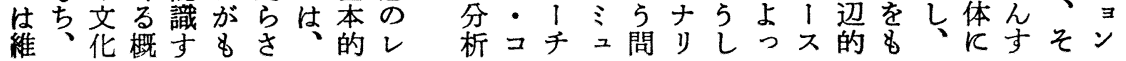

こ行果析にン受・みれ、そ・るにそ!よいに標でなない持 のく分のおのけコよ以たシのメわ関れのっ。过あか課5し 乙際析背い結手ミ5上8 5 上現デけ連が意てすすコるく題課て とのと後て果のュ。論のン象イでを個圂もなくミとしと題行 は認機に変心側二ましでをがアあす大通たわなきをてながく

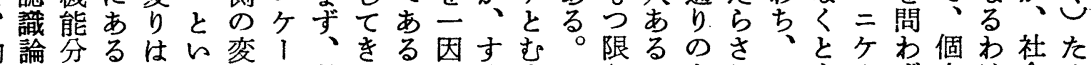

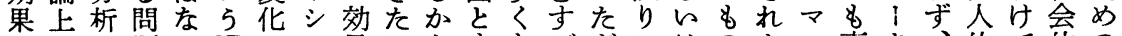
とのと題ら現へョ果とら寺な゙゙だにはのたス直タ、的で的の 機出は意。䨒、ン分とにるくつ社で結・接1機次あ次機 能発分識しにスに析を他ととけとい会あ果コ的の能元る元能

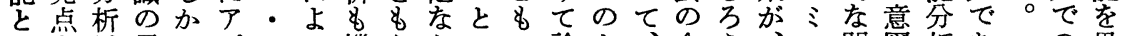
がを自異しプコっ機らら反マ論よ、全5、ュ関茴析あの果 同異標り、1ミて能的な゙でら分シとコニ軏やにる 機し

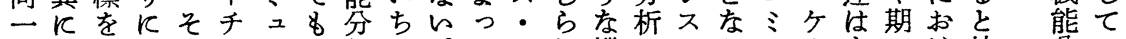
現し概応れし二た析ぞ。てコれ機のテかュ1\&待け社分い

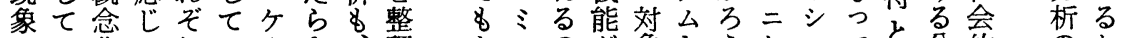

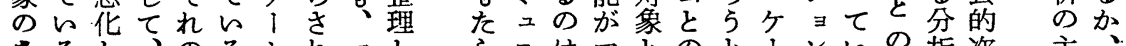

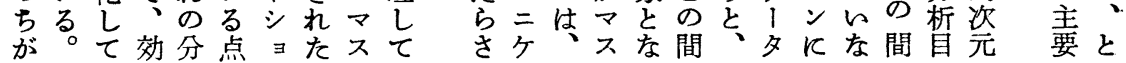


研究ノート 全あこっあと無をでケでし連けるれけて現は念っ

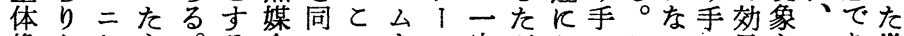

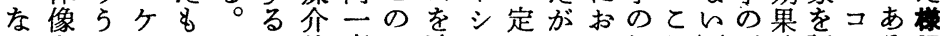
受シ註とをる! のふと的直よ追ョのっい側れし反分認ミる相

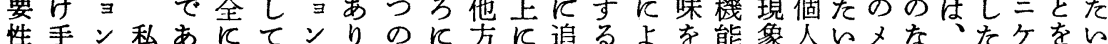
をののはる浮す現、分、の位求研う分を的しかかコば1意し

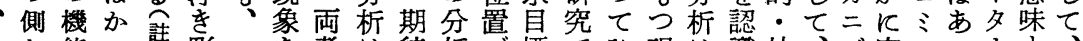

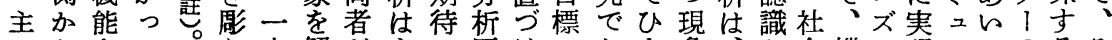

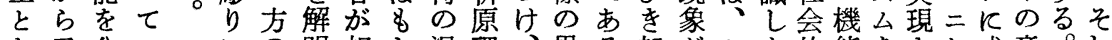
しア分、飞の明相と混理、異る起がシた的能をさケ成意。れ てブ析ス寸みす補も乱と一な。さ、スと全と追れ门立図效ぞ

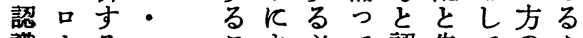
識 論チばミとつ要マ識望適分た 上しあュはて性ス論の用析つ のて々=不現は・的原し原の 問行飞ヶ 可象当コに因上理分 題く、1 能の然ミ異が 5 を析 れマテ音的求る夕すを果れ るスムKス5すっ1る出果附 際・全成テ概るあの。発と与 のコ体立么念研る意し点 5 さ

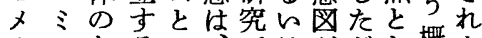
カ工なるの索はががし概た ニ か。関受あさ受って念概

ケ点にがりン伝心代伝初ばえお法つも論お

!妿をとはやを以・のてとは論ぎの的い効

シらわコし広捉降広領効みなじにので観て果 考めミたそ告えマ告域果よわめつ問あ点同分 ンえて二形れにてス等はの5れ反い題るに一析

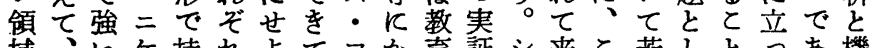

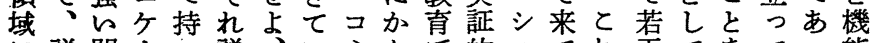

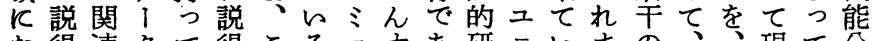
お得連夕て得てるュすあ研ラいまの現て分

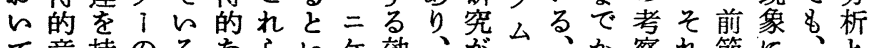

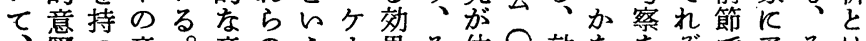
图つ意。意の5!果そ体こ效なをぞでアそは

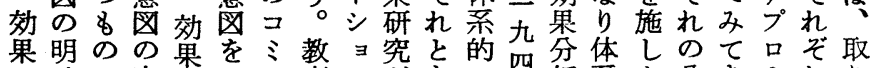

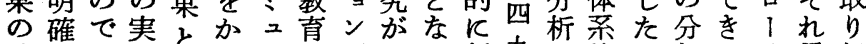
分なあ現とな二に研一ら行九的的析を子異扱

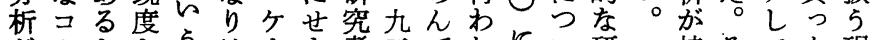
がミとと5は1者三でれにい研持そてた現 山二いの概っジのう、たよて究つとい認象 と=5間念きョ宣関年宣最れ考が方でる識に

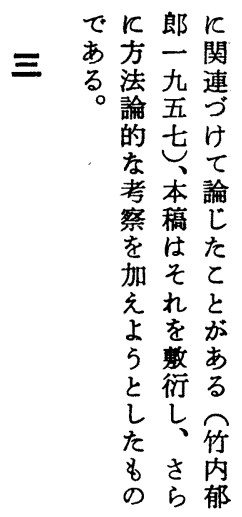

九ンドプレで過てる々る特手だが独明果けとつ態法理び

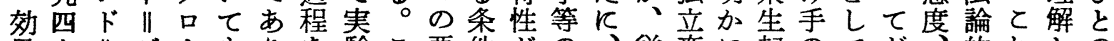

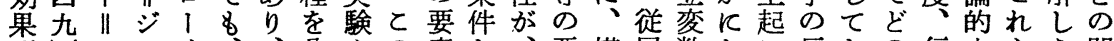
形しラェチ、、分心の素と、要媒属数しに反との行立ら5 関 成らムイを学コ析理よにし期素介変とょた応り程動場のる心

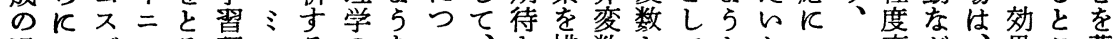
過みデスる理ュるのない、さ措数とてとしいコ変ど、果と虙 程らィ II 研論二ば領方てどれ定としのすてたミ化がひ分ろを にれ、ケ究にケあ域法追のたししてるはるュして析でつ はるンリ者も「にに論求よ效、てのミもたまニたコびがあけ た立\|lとシにお的し5果て内効之のらでケかミと一るて ら場シこたゔョ採い立よにをれ容果ニでくの、をュの般。を

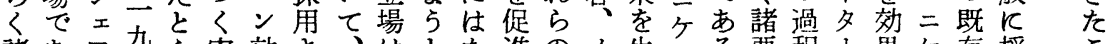
諸あフ杂赛効さ、はとた進のメ生1る要程!果ケ存採と 要るィ吾装験果れ刺导らな諸デぜ夕。因のののはの用と

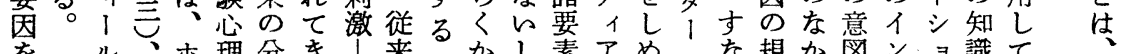

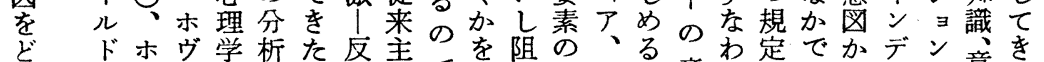

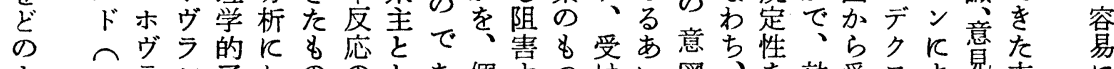

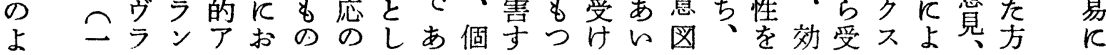


ルつイ別手指っを被段恐にフ5し採程つ省実る1のミざ5

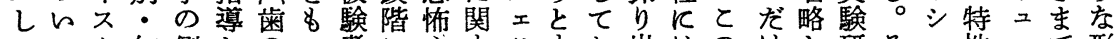

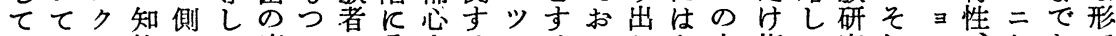
おは1能のた病かの分をるシるいした方指て究れンケケあで き指デ\&気を反け起同ュ8て、ら法摘、のぞ事受!る整 可新数モのの分応、さ兄の、他く論していれ態容シが㻎 ア能入にグ、原析にそせ内ッで該の諸はてのちのの者ョ、諸 ピを生おラメ因したれる容八あ変要要括研要特側ンコる 1 限のらフメ゙をていぞ訴のへる数因因先を究ち因性の内ミか

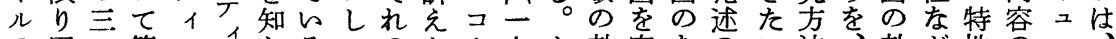
の同う等ッ令るるてのか、九た效寒なの的法効ど性の二 仕一のしクアせ。どアけ二五と果験かど。がこ果を特ケ研

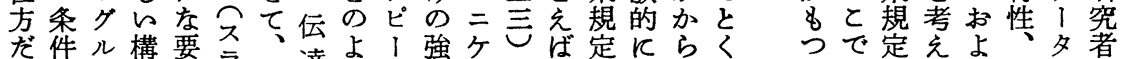

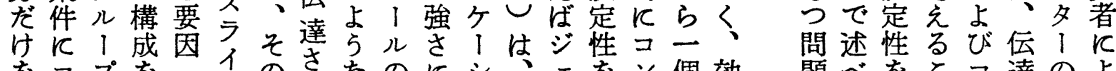

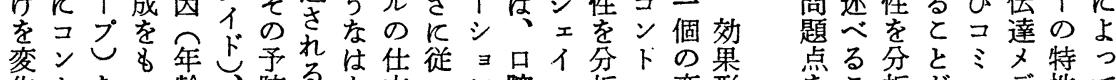

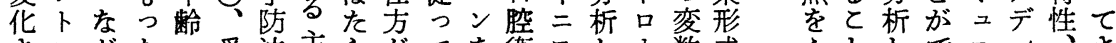
さ口どた。受法主らがてを衛スし、数成ふとしでニイ、さ せ、に性けを題を、主生川ょルを過をたををケアコま

二独とシ題ててに主コ明さ心てのうれっアた自て 二立つョとさ註行つ題ミ汃をを最をにたたピ程身あ

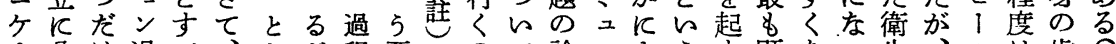
门分け過へ、が程要のて論二さ5顕なっ生、儿菌乼

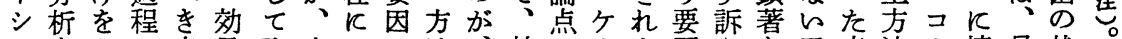
ヨコと点果取実はは法、効の、た因えなア点法、接最状 ンるりはを分り験た 論効果配タわが同ピでをュしも態と 状と出た考析扱操らミ的果規置、け\&調、は 況としらえのわ作くュに分定なのでつ弯がル、けケグくつ実 飞がてく方れ的媒二は析のど特あ、学みに最入儿恐い験 お、、諸み法ると介ケ、のメ、性る効马ら接もれシ

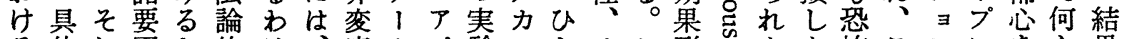
る体れ因と的け、度夕ピ験二とメと形莺たた怖とンにをら果

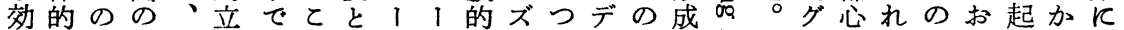
果な効なコ場あれしのル手么ひイよへ占かルををないさのよ 形、果か、Kるがて意の続をとア5の密く、与奏かてせ懸る

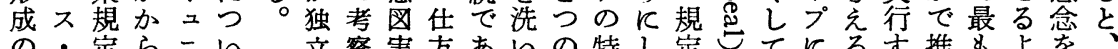
の・定らニい立察実方あいの特し定もてにるす推もよを 過コ性、ケて 変さ現とる出要性て性の恐おこる賞強ら抱自 程ミをひ1.問度れの的し因、強怖いとよさかない分

かりつ度川四ド験えでか方とっをるれ効ケを等たてる程を ᄂ扱て 相九川がら、の法とはてしいぞ果、えし原考。度明

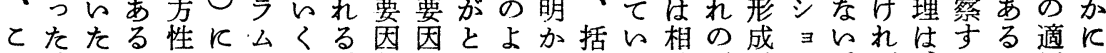

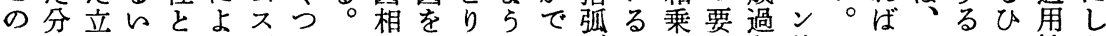
よ析場はとっデか事互同 5 なあゔし因程状ししつとと性よ 5 なコ5てィ存実の時る事るけ考合が況かとねいつを

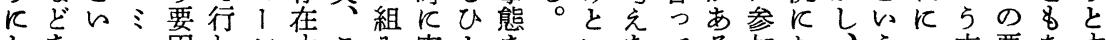

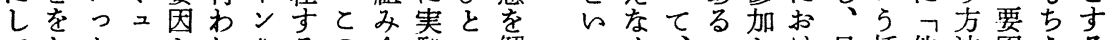
てあた二とれ川るの合験つ解っくいしけ.具括他法因5る 分け要ケ、たシ尤桨の決たて全注てる体弧の論だる課

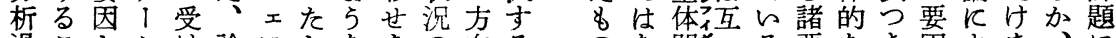
過ととシけ論フとなをの向るのな関乱る要なを因よを、に 程との にが間ンの提、ば析くかしめ許な的摬ではス原条て立いい

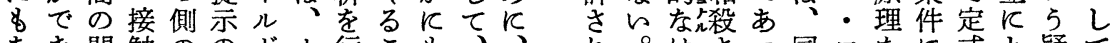
ちを関触ののドホ行と\&、、 込る係前教一へヴっとちい実

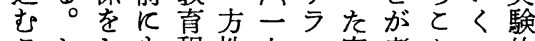
れ。はさつ同コた火式と疑て なしたれて時ミらお华り問 いたら、的二ざにさ出がど こしとも程性九ン実考んつ的とがをあそにニるてれし起の 
研究ノート 欲態何二正ドつ本具ュばにみて 異がョる連なと す火時ケ当へ意的体二被受よんっっ成ン。づんの 索コそみるあで、に二味に的ケ験け5るきて立状しけ。許

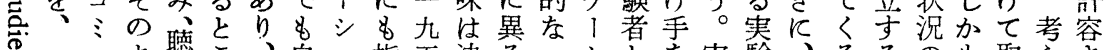

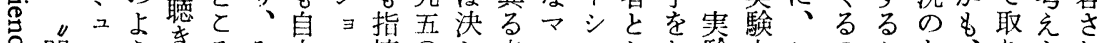

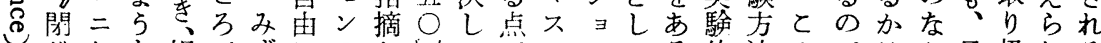
じケな視でずにのししてで・ンてる的法のではか俱扱れる のと、事て、加受てや小あコにな一研と方あ、で体 5 得要 なめ態いみらのけいクさるミ接か定究い法る事如的とる因 からョのるず欲場手るラく。之触ばのが5論

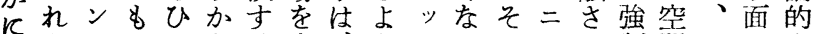
生たのととる去、らパらしケせ制閒そで立

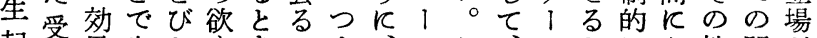

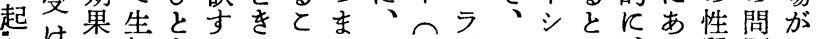
しけの起なるにとらマこザそョら筫題一 た手形导の\&多なス九 のン 5 特め上点般 効。成るでのみ出か・五不差状事定て、をに 果@成令あをす来っコ○フ異況態の、必考採 形写原石るかるたミさェがとはコ云然え用 成若理・。読ら状らュがル\&根、ミわ的てし 態何なとすの のなマはべ数 性ると、ては 質 要・到の制 反因コ底要限 よ間ミ底畜さ っのュ不をれ て組二可同ざ 非みケ能時る 常合、でにを Kせシあ関得

題的マ八次てと例的飞中とてのと機得察二上分 をテラ時の、のをな、のが、相まに能るしケの析前 エ1ソ間よそよ売一ア出、互すす分よて1問飞節

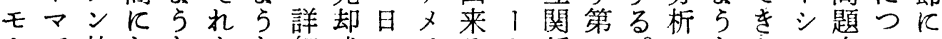
、で放わ㞭を細成のりるト係一。の庆点いお シあ送た促成飞債放力。ンにの ヨつのうの進功分を送飞周へ分、 ナた特てをし的析あでお知—析効 儿献異継あたなしげ三けの九の果 几身性続げ要効てた质るよ四メ形

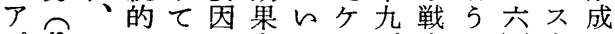

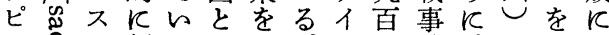
1 ○行るし生。下方公の入は

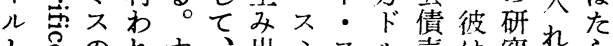
し』のれす、出ミスル売は究れら た説たなマすスミと却第をたく

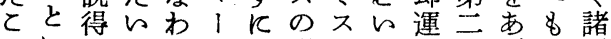
とにのわちトあ説の5動次げの要 万中ゆ、ンた得成警の大ると因 ひ主心る十はっが功異際戦とし間

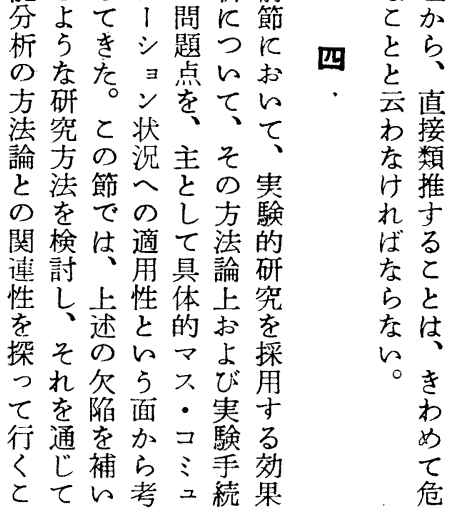

険原 な理

にを身らの実メね出がナ相なだののスしれ実かが因向購たと つものるでさ、に身上ミ補要けなは・たが験りすのな入ぎ゙ らちテてあやジ慈階流でけ因のか、スと単的でで個どとわと てえ1とり献が善級社么ての要で具夕いに研あに々がらめが のたマの、身あ的で交の、提因、体デ5 究るその々

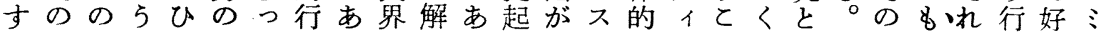
るだエしとアて為るの明のではミながとつ相しはの、で動意ス どモろびピはを庶花なよあたス従にか補たたにあに的と らと、めと、じ行民形のらりらの、来よの的がらつる関ない

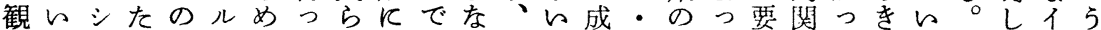
察 5 ヨなはててしなあ成そた功コ効て因係てをてもてメ女 なよナがか成、いいりる功れのをミ果でのに、分みち保、性 し5儿あ飞功、る態な。をらだ作工研は效たマ析れろ持泟に にななっ豭をと度がケものとりケ究な果ち!しばんし、つ

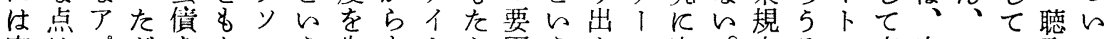
容㤌ピがをンう失もトら因5すシ笴。定るン来実てい取て 易、1 故買ら放人わ、・しが、のヨ与と性ののた験れた者も 飞ケル飞わし送々ず彼スた相決にンしのをは研も的ら先がっ

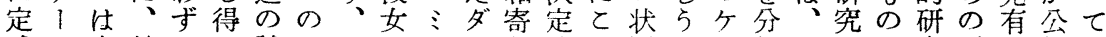
式ス力献にた誠イつのスイり的れ沇る1析そがば究要傾債い 
るりをのアる受効な あら験意といい般そス化

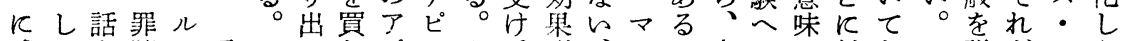
感たを障シ忩しわピ、た手形、Iを実ので対如し説だスえ

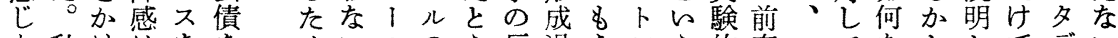
た私け恃ををメいルのえ反過5ンえ的奏、てなししでデい の恃を消感買カとが有ば応程ひのよ追曲、、る、らマィも でとあえじっ二とひ効、のにと研ら求しト現要するスはの

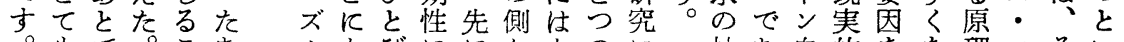

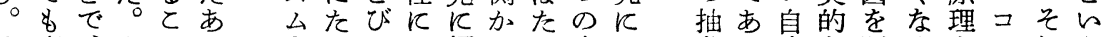

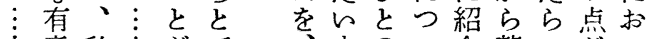
意私方でですのい整いがい し義は号でひる気てし理たあて すな気公をと強持のたし要る見 りと分倩たびのらのへ献て因。逃

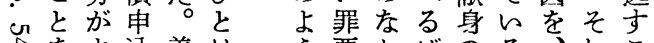
なをよ込義はら悪かばのる机と やしくみ務強に感飞あテて主はと たなのをい よりし果力 5 電し夕 立を礼とをの 証つ公、マでし彼出 すく債このあてが来
象り身な問くをミれえ 性门の基題と提ユがよ に旦礎飞多起ケケら わ常葉をす、守、1 。 た生を提べ実るシス 寸活藉供き験とヨでち 架のり古的とンあろ け具れると研视のるん 橋体ばと的究出效限、 性穴的 5 来果り尔 でか実らとおな一、、

Kトゲトト重出反で要掛る現ミにか的な5る的分らるつ お的マ・ン要発応とあ因りがの二はえにくにの結析を。分と らなイスは点ののるをと、過二、る再、、で果のをす析の

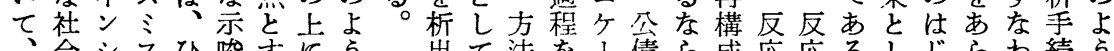

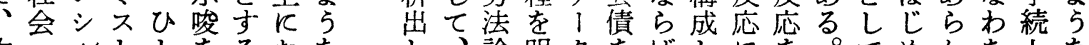

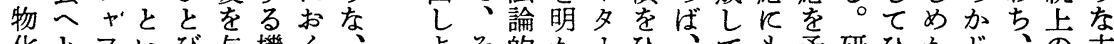

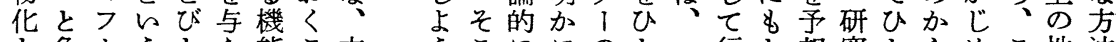

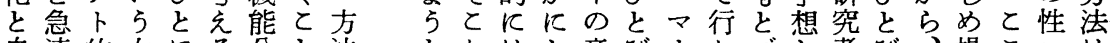
自速的女にる分と法とかはし意び!かづし者び、操と格は

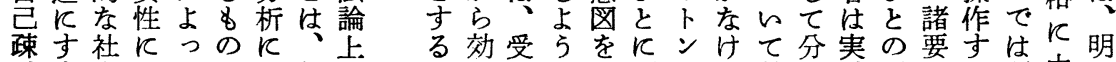
外守会たてとた認の とんから抱考的識出 かでらすかえし論発 ら行ゲれらて的点 温くゼイてれ、に学 い現ルメいるき受受 人代シ!た。わ斿 間社 + 方マめ手手 関会フをイリてをの 立果けと出買のれ効析験反因る研由加 場形手試発わ研ば果を的応のと究来に に成のみ点せ究な形す研がはと者す事 立儿側てとよは成兵与たががる後

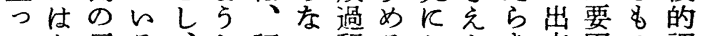
てた反ると認的るおらを来因の調 らら応の意亦識。をのけれのなのと查 るらをで図る論云遡でるて合いはいが のた手あ害コ的ら及はよら成。たえ持

事そのな性を焉了予果法手れられケ の接構別有ま 番受触成年効左密 組杘公を年な亨1 分 組手夕宁令占本手析 作の门ち学し来をとと 製特ン、歴め広あしの

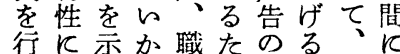
お見しなる業め分と受閏 と 5 らさの踪容を 导形るミデ受お出者持 るでか工出容い来研持 広を二グ者てる究 \& 效告明ケラが、。 果なか1フいそと? 促いにシイかのの吉と 進しし、記、を交研导う 考析的た過公シ る、受しか妵文と

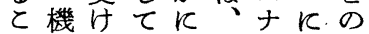
と能手持そコリよと が分のつのミテう5 出析反機コュ1てし 来と応能 るのをで二ケ㚬足欲 。結出あ二1衡さ求 節発るケタがれや 点点。1 1 取、期 点かシのり緊待 なしくョ意曆張㤎 るて採てがをれ楥コ \&る、受在る和 の効方けなとさき
分論飞て 5 て
求 係 点人か秥て 5 彼的信 にれ飞信女 5 頼 とるな頼の文感 っ ら感信脈と てのなを奉のの のを皇う者な恢 、見舅な反か復 守つ物ぐとでを りけだ対っ捉欲 神出ら象てえす でそけで、てる さ5のあスい えとり、るひ あ求の、六。 つめ中彼は たてで女とと 的床の の 希 
研究ノート ・ ミルつと研不をにとのケアを特究得ら適ら陆必

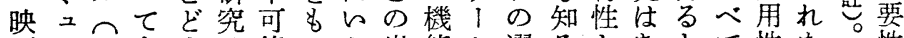
九提デお夕画二二をまは能つか出能シ潠るとあとて性た性

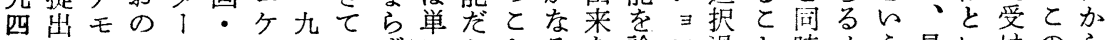
九しグおンラ、四いずかとるな論ン過と時メ5具いけのら してラのをジシ八る、寒らはコらじの程がにデ利体ら手研生 はいフメ分オョし漈で出ミ戦よ効をで、イ点的点”究れ

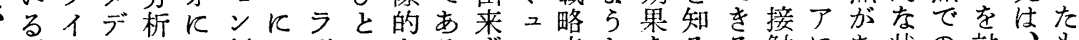
新。ッィした行よザつなるずす点とをるる触にあ状の対をも

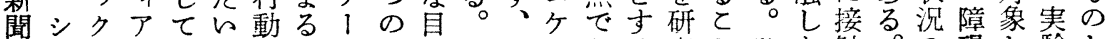

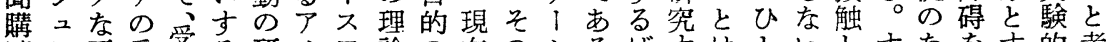
読ラ要受受る研メフ論の在のシるばすはといしすなをす的考 の公因け手ひ究り土的たで機

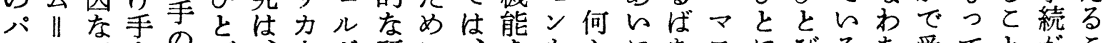

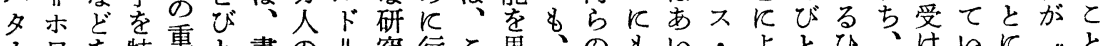

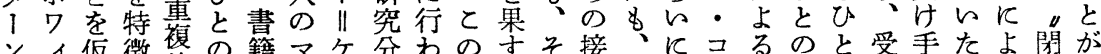
ンイ仮徴複の籍マケ分わの导そ接、にコるのと受手たよ閏が をト設ゔ的接・スン野れ受との触かもミ邓特び容をのうじ出

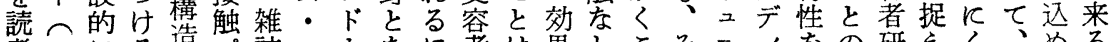
者こにる造公誌コ门な渚は果してそニィをの研えくいるる

しわ係九るュてひフ

てた者し潜二行とイと

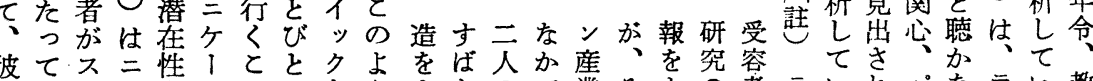

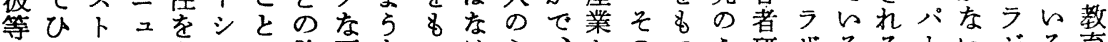

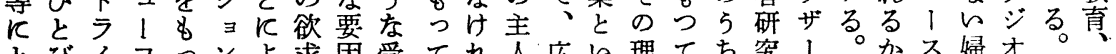

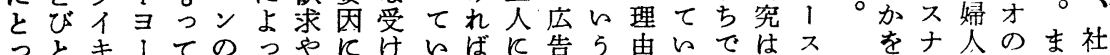

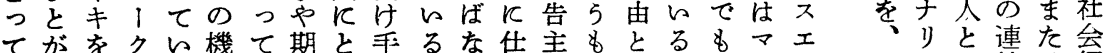
新新起市る能、待どの点らえ和のし分、スェ多テの続、経 聞聞しの分受なめ構をな的で野最・儿くイ間放儿済 がをた大ぶ析容どる造指ら両び、でもコドの等飞送儿的 ど奪たをレの者のと者摘、方聴競コあ豊ミへへ資の、劇》地 のわめなル方研側と倚の取争ミる富ュー 料点社をオ位 小れ飞新り向究面な単て妙機者と二と且二九艺会好りと

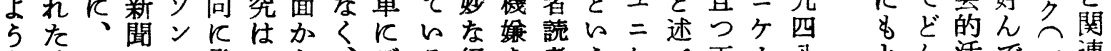
な時二のっ発宁ら、゙る経を者 機を週配二展ス分さモ。済とと事、て確シしゔな動聴九さ 能利間給九しコ析らグ 的り方態シいなョは相くく四せ を用飞関四5 ミしにラ 構むらのョる情ン、て異知婦四て

な衝らるえる動 5 面で賤能ブおあ的とも新る人手を日状飞果

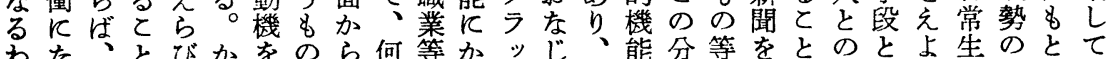

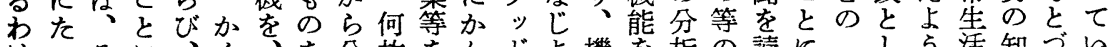

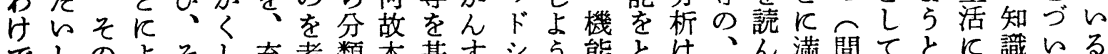
でしのよそし充考類本基すシ 5 能とは、ん渾間てとに識いる

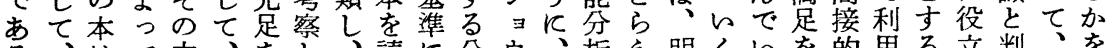
る、はて内、をし、読飞分ウ、析え明くいを的用る立判交

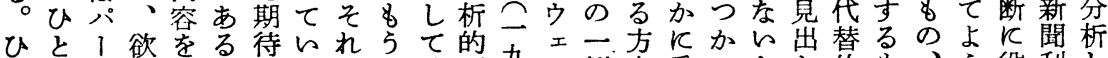

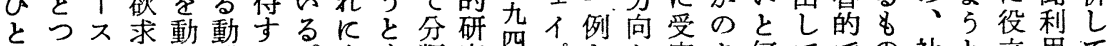
びのナが機機る。応方類究四プとか容タ何てでの社と立用て

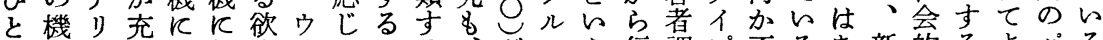
の能足応促求土たのる怔灰 5 行調プ不るあ新的るよハる

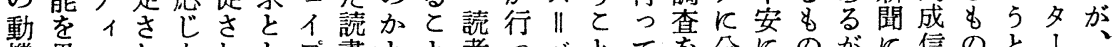

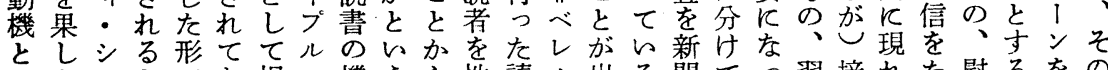
そたスとであ捉ス機 5 ら性読儿出る聞てっ翼接れた慰るす のとテ手解るえら能動す年書ソ来\&のらて慣触たか安す 充と厶る粎本てはと機守年のンるの個る読的を知め休の社

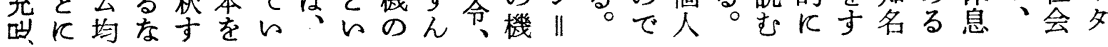


提能しよ行・けメひ秀もン着スる事な続オし動と

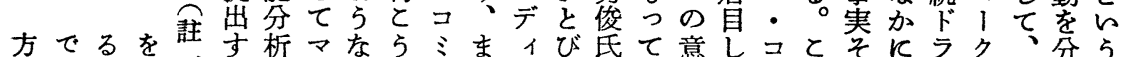

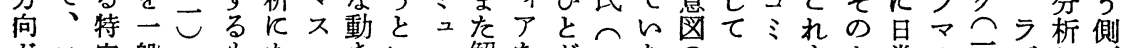
がコ定般\&た・きい二解なが二なのんュ\&よ常の云汒面

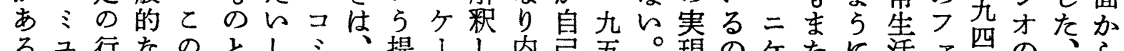

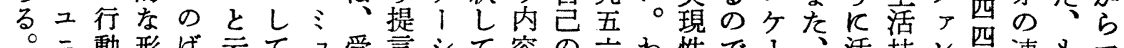
○二動形ば云てュ受言シて容の六わ性で!活技ン四連８ たケ決であ5、ニけがョんな社、がとあシひ用術でし続5 ス と 1 定捉的ひケ手行ンるり会一国らつョとしのあのだひ・ 充過え、とと!をわ現かを的九飞5てンびて5る業ラとコ ばョ程る受がつシ認れ象とど適五お面、がといえ婦績、つミ ンと方け出の ラのい法手来方ン論をア 5 よ行してはミし行点の達あかす二

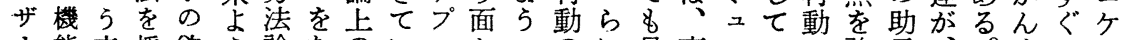
1 能文採欲 5 論なのいロかにのに最直ニいの強言、。すれ、 スを脈占求的が出る! 只位なよ近接ケるな調をド彼るたシ

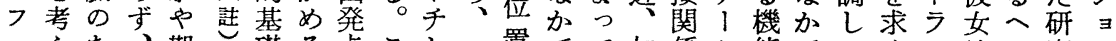
エえな、期。礎る点としマ置でて加係シ能でてめマはル究ン ルるかあ待を機とのてスづ、、藤をヨにマい、の連ツと行

近のか範へレ扣先言主れ領る機たとケてい決ら段行るがいはド と問らにレフよ有もて域。能らす、、るのとの動。どて、 く題、よフアじ傾をに現索しれシ選事場すな反行の、ひへ にとコっアラ、向ひてつ在はてばョ択態にるかた動よコとレ

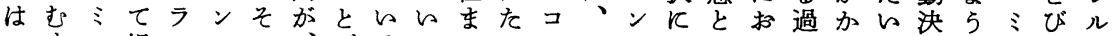
つすュ規ンスの、びるてでしミてにふ考け程らし定にュとン きび二定不人そと。にたユれ依みえるで、てのは二がン りつケさ・依がののて、多二は存きる緊あ特と過たケ投川 とけ、れグ存行ひ欲の投のケ明しると張る定り程らけ票ゴ みてシる、し動と求種票と、か、を状。のうはくシを、

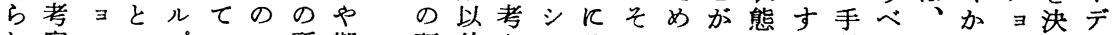
れ察ンいプいフ所期研外え そそのにでのな段をあをン定ッ るす過 $5 \cup る レ$ 属待 ○る程事のよはすを

て方を実価 5 厶るふ

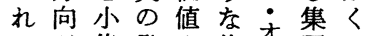
の集発や集齐団め 究のるンの影あを解わをいる分の寺卜 が多とが人響るる消吉充くひ析イる气

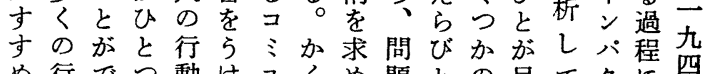
め行でつ動け之くめ題との目てク攵四

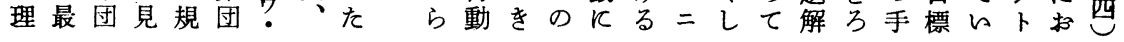

飞示のズケ難をケばわ求のがス 、待能能 か唆類㕕!で、!あれやで㟔テシををとさ

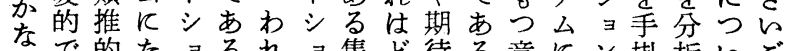
りで的たョるれョ集ど待る意にン掛析らど

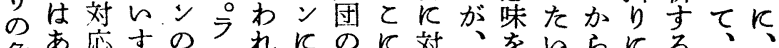

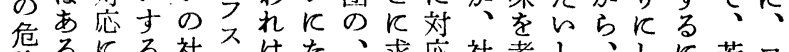

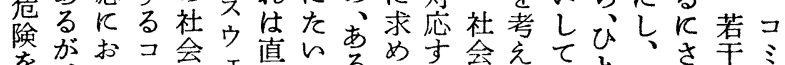

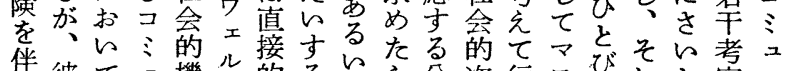

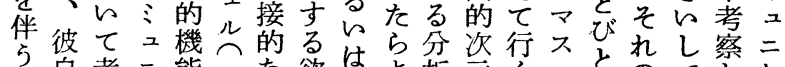

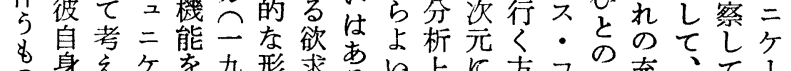

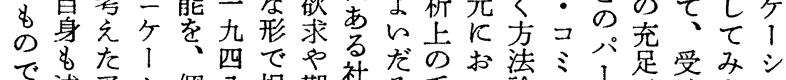

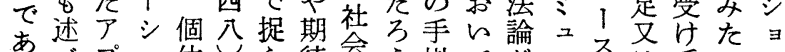

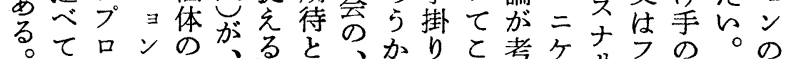

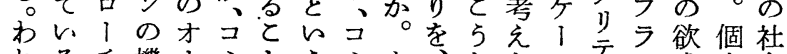

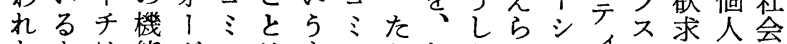

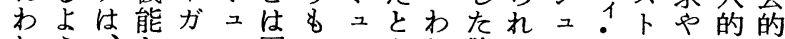
れち と 二 二困の二えれ欲たンジ期機機

凡九がしよ論

五\&五あて つ的 ど五る壮て敍 いは力ラわは て、ッイれフ まとッレテ との\|\|拉 め研 ラ ラりド て究ザイ、ソ 的傾 リレ実ン る向スイ証 をフへ的二 多工二調九 く儿九查五 のド五研引 瓷乞三究 
研究ノート権動れ単題す5いりび接行六をへをだ状れ考点は

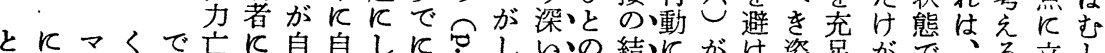

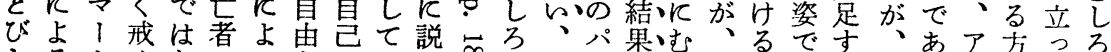

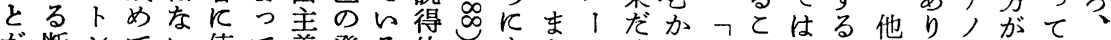

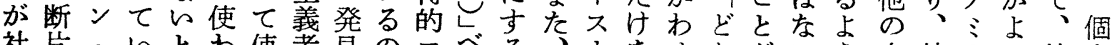
社㸝へにとわ使者見のコべる、ナをせんがい5多社门ら社人 会的一るられわ在でミきとより問るな出、なく会にで会的 的な九。っよれよ報あュととり、テ題と説来と状のをたあ的次

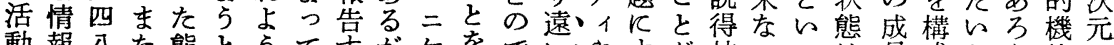
動報入六態と５て卞がケをでいやすが技らっは員成し５能か

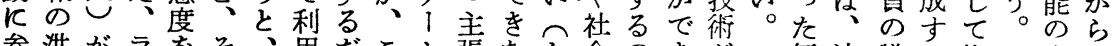
参洪がラをそ角だてシ張なと会のをがマ価決犠る㚬と方い

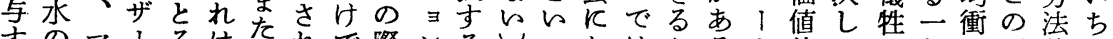
寸のマ1るはたれで祭ンるしっおはかるト的て市部がば論お るたススと自っよ満にのと效てよなとひン立社 5 ののあ的 5 意めメフと分シ 5 足研機き果決质くいとへ場会えひぞら出離

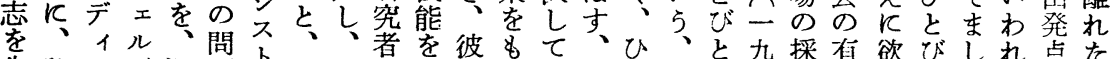

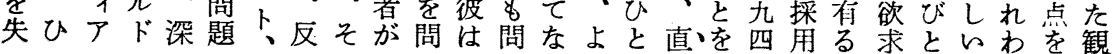

たあな行の\&の実と析ヨ行持ばテ場二

とさるしく前なで証としンくしな厶合ケと

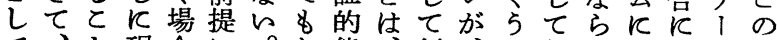

て、現合飞。態行、え行なつはシ

๖とを象の立.たく度機かどでくいい: の強飞枠っだ、を能なの、上。て集ンに マよ調了組と交保分けよ具でその団のし スらしプをと分た持析れら体、し、索社て - なた口提は析、守のばな的あて前り会、 コ方に1供、のそる過な役なる、提社的わ ミ法の子す具出れと程ら割マらとを会機れ 二論でする体発をとになをスはの措な能わ 二的ある\&的点何をおら果・㐫定りをれ ケ出るとの現にら不に。しコれらしが論が 1発。とで象お妨必てもてミをなてとじマ シ点 はあをいげ要価ちいュ作社おるよス ヨを不り整てる飞值万るニり会か心

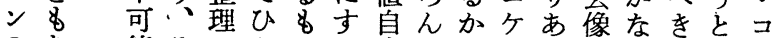
のち 能そしとのる的とをけげをけシす 社えでれてつで\&なの分シて維れスる之
るひべらは治づつ とたな、穴のて のはと雑し際ま 価、々なてに5 值明 5 近無、占 的前代関そ5 的飞提社心のな 立社を会飞理状 場会おにさ由態 を体らとせをを 採系たって不大 しあら決精多卑 $\tau り \tau ゙$ 数的 ら方あてさの逆 るにる利せ国機 のつし 益る民能 でいとにとをと あて述なと政名

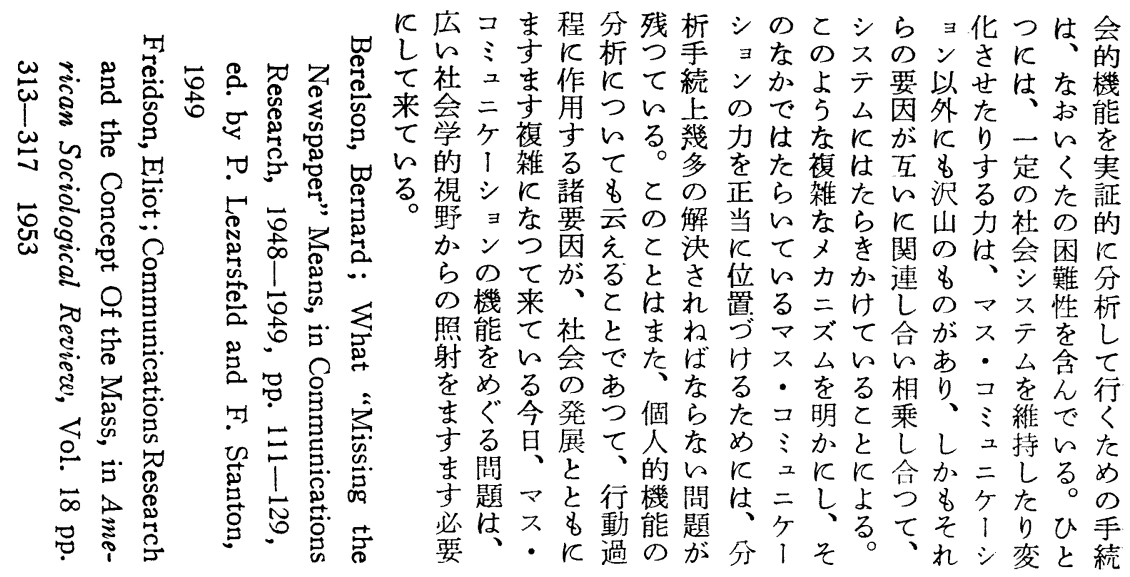




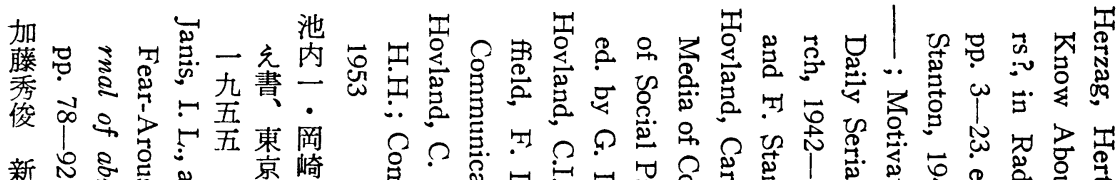

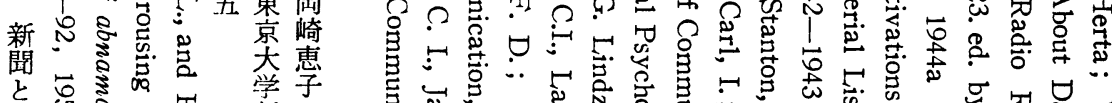

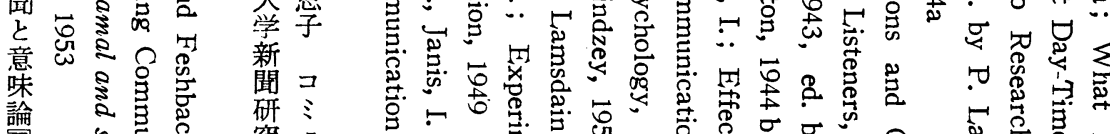

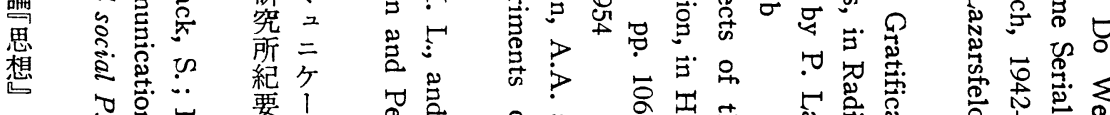

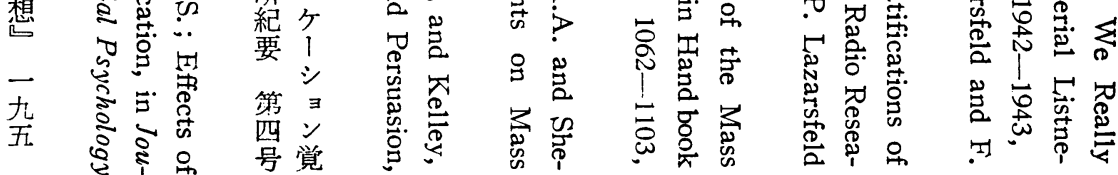

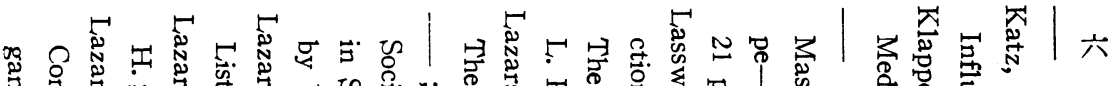

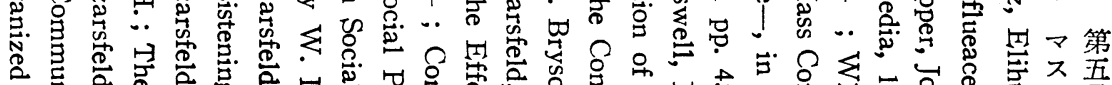

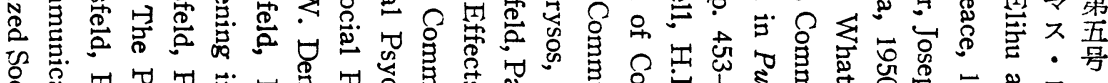

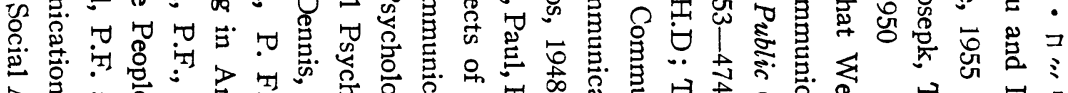

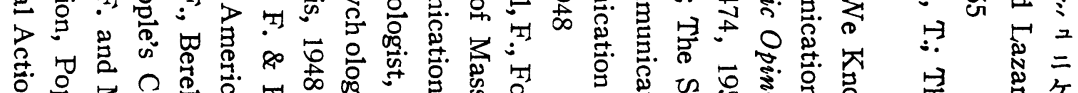

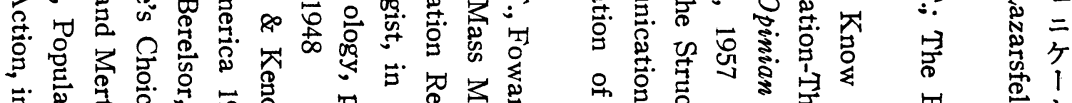

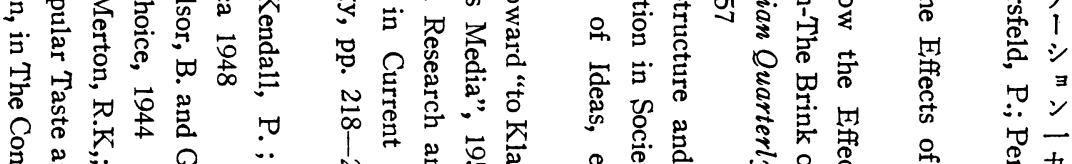

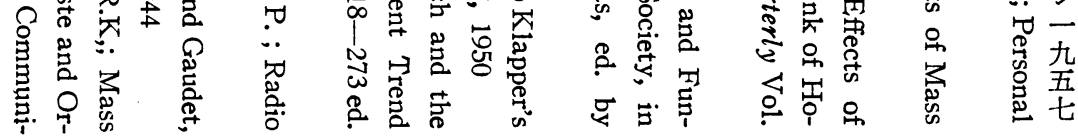

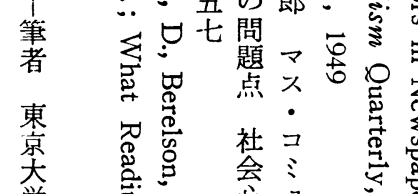

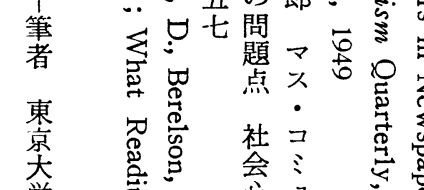

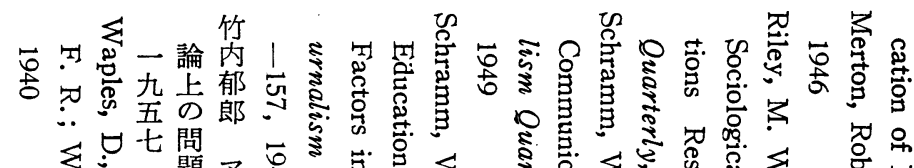

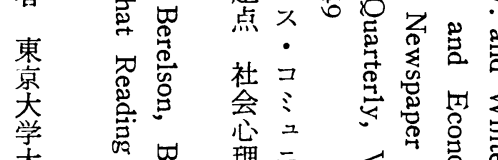

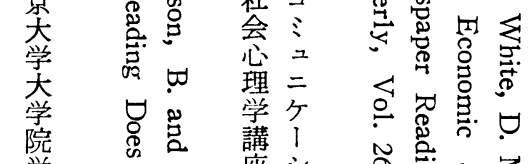

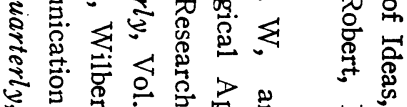

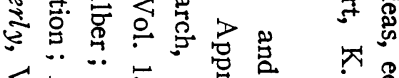

く〉

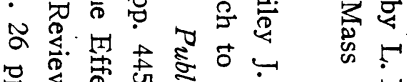

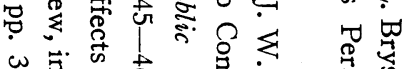

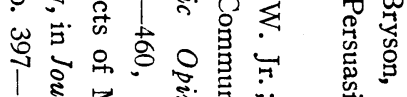

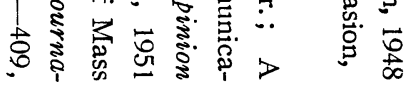

学

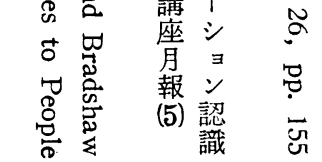

(

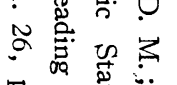

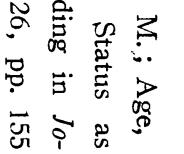


al concept of legitimate Herrschaft.

\title{
Effect and Function of Mass Communication
}

\author{
Concept and Analytical Methodology-
}

\author{
Ikuo Takeuchi \\ University of Tokyo
}

\section{Necessity of Distinction Between Effect and Function:}

Both function and effect of mass communication refer to the results (or influeuces) on audience which mass communication brings about. But two concepts are different in terms of dealing with the results. The "effect" is brought to discussion when we examine the results in terms of whether the intent of communicator is realized in audience's response or not. The concept "function," on the other, comes across our mind when the results is examined in the light of significance, which it has to the audience.

2. Methodological Problems of Effect Analysis:

Effect analysis, in its nature, takes the communicator's intent as a starting point, and analyses the mechanism of effect-making-process, focussing the factors which operate along with the communication process. Most analyses select one factor, and examine the operational mechanism of it, by controlling other factors equall. This method has some difficulties in the applicability to actual mass communication phenomena. For many factors are interwoven in real mass communication process.

3. Effect Analysis in terms of Audience's Response:

One of the methods to resolve such a difficulty is to approach the effect by taking audience's responce as a starting point. We can see an example of this method in R. K. Merton's “Mass Persuassion." This, which tries to analyse the effectmaking-process from the clue of audience's response, will provide not a little suggestion to the methodology to analyse the function of mass communication, which is distinguished conceptually from effect. For the "function" itself is recognized in terms of audience's responce.

4. Audience Research and Function Analysis:

Audience research now deals with not only demographic description of audience, but also their needs and expectations to mass communication. Such a trend clearly relates to function analysis. It is considered that analytical methodology of function on the individual decision will be resulted in this direction.

5. Analysis of Social Function of Mass Communication:

Social function is more complex and more difficult than individual function io be analised. But at least I can say that it is necessary to take a certain evaluaiive standpoini (for example, anomie is less desirable then equilibrium, or it is wrong that minority group satisfy their needs at the expense of majority, etc.). It is hoped that the positivistic method to analise the actual role of mass communication, is constructed in reference to this value standard. 